\title{
KONDISI KESEHATAN KARANG DI PULAU - PULAU KECIL TELUK JAKARTA
}

\section{THE CONDITION OF REEF HEALTH AT SMALL ISLANDS OF JAKARTA BAY}

\author{
Dedi $^{1)}$ dan Taslim Arifin ${ }^{2}$ \\ ${ }^{1)}$ Program Studi Ilmu Kelautan, Institut Pertanian Bogor \\ ${ }^{2)}$ Pusat Penelitian dan Pengembangan Sumberdaya Laut dan Pesisir, Badan Litbang KP-KKP
}

Diterima tanggal : 8 November 2016, diterima setelah perbaikan : 27 Januari 2017, disetujui tanggal 7 Februari 2017

\begin{abstract}
ABSTRAK
Tingkat pencemaran perairan Teluk Jakarta yang terjadi diakibatkan aktivtas dari daratan memberikan dampak pada perairan di sekitarnya.Terumbu karang sangat dipengaruhi oleh kondisi lingkungan. Tujuan penelitian ini untuk mengetahui kondisi kesehatan karang melalui persen tutupan karang hidup, sebaran dan kelimpahan penyakit dan hubungan antara persen tutupan karang dengan kelimpahan penyakit karang.Pengamatan dilakukan dengan menggunakan metode transek sabuk $1 \times 1 \mathrm{~m}$ dengan transek garis dengan panjang transek 50 m pada kedalaman 3 m, dilakukan pada 5 lokasi, 3 stasiun di Gugusan Pulau Pari dan 2 stasiun pada pulau yang berdekatan dengan Teluk Jakarta. Untuk mengetahui kondisi terumbu karang dilakukan analisis dengan menghitung persen tutupan karang hidup, prevalensi penyakit karang, kelimpahan koloni yang terserang penyakit karang. Hubungan antara tutupan karang hidup, prevalensi penyakit karang, dan kelimpahan penyakit karang dianalisis dengan metode regresi linier. Secara umum kondisi terumbu karang pada lokasi yang berdekatan dengan teluk Jakarta dikategorikan sangat buruk $(0,56 \%-5,05 \%)$ sedangkan pada gugusan Pulau Pari dikategorikan sedang $(17,88 \%$ - 41,27\%). Kelimpahan penyakit karang yang ditemukan 17 koloni White Syndrom, 65 koloni putih, 2 koloni Brown Band Disease, 1 koloni Skeletal Eroding Band sedangkan kategori gangguan kesehatan karang seperti Fish bite (4 koloni), Drupellla (2 koloni), Crown-Of-Thorns Starfish (COTS) (1 koloni), Pigmentation Respon (31 koloni), Invertebrate Galls (13 koloni), Spons Over (30 koloni), dan Sedimentation Demage (64 koloni). Prevalensi penyakit yang ditemukan seperti Skeletal Eroding Band 0,46\%, Brown Band Disease 0,93\%, White Syndrom 6,48\%. Prevalensi gangguan kesehatan karang seperti kerusakan akibat sedimentasi $(37,96 \%)$ dan Respon Pigmentasi (20,83\%). Korelasi antaran tutupan karang hidup, prevalensi dan kelimpahan penyakit karang memiliki korelasi yang erat dengan nilai masing-masing 0,7794 (korelasi persen tutupan dan prevalensi), 0,9139 (kelimpahan dan tutupan karang) dan 0,8658 (prevalensi dan kelimpahan penyakit). Semakin tinggi persen karang hidup maka semakin tinggi penyakit dan gangguan kesehatan karang yang ditemukan.
\end{abstract}

Kata kunci: Penyakit karang, kelimpahan, kondisi karang, Teluk Jakarta.

\section{ABSTRACT}

The level of pollution of the waters of Jakarta Bay, which occurs due to the activity of the mainland have an impact on the surrounding waters. The coral reef is strongly influenced by environmental conditions. The purpose of this study was to determine the condition of reef health by looking percent live coral cover, distribution and abundance of disease and the relationship between percent cover of coral with an abundance of coral disease. Observations were made using the belt transect method with a $1 \times 1 \mathrm{~m}$ long transect transect line with $50 \mathrm{~m}$ at a depth of $3 \mathrm{~m}$. observations were made at five locations in Barrier Island Station 3 Pari and 2 stations on the island next to the Jakarta Bay.To determine the condition of coral reef analyzed by calculating the percent live coral cover, prevalence of coral disease, abundance of colonies coral disease. The relationship between live coral, prevalence and abundance coral disease can use analyzed by regression linear method. Generally, the condition of coral reefs in sites adjacent to the Bay of Jakarta categorized as very bad $(0.56 \%$ $5.05 \%)$ while the Pari island cluster is average (17.88\% - 41.27\%). An abundance of coral disease were discovered 17 colonies White Syndrome, 65 white colonies, 2 colonies Brown Band Disease, one colony Skeletal eroding Band, while the category of health problems such as the coral Fish bite (4 colonies), Drupella (2 colony), Crown-Of-Thorns Starfish (1 colony), Pigmentation Response (31 colonies), Invertebrate Galls (13 colonies), Sponges Over (30 colonies), and sedimentation demage (64 colonies). The prevalence of the disease found in such Skeletal eroding Band 0.46\%, Brown Band Disease 0.93\%, White Syndrome 6.48\%. While the 
prevalence of health problems such as sedimentation of coral demage (37.96\%) and Pigmentation Response (20.83\%). Correlation conduction live coral cover, prevalence and abundance of coral disease have a close correlation with the value of each 0.7794 (correlation percent cover and prevalence), 0.9139 (abundance and coral cover) and 0.8658 (prevalence and abundance of disease), The higher the percent of living coral, the higher the coral diseases and health problems that are found.

Keywords: Coral diseases, abundance, coral condition, Jakarta Bay.

\section{PENDAHULUAN}

Pulau-pulau kecil di Teluk Jakarta merupakan kawasan yang banyak mendapat tekanan dari lingkungan perairan disekitarnya. Kondisi ini dapat mempengaruhi kehidupan biota yang terdapat di perairan sekitar. Beberapa penelitian menyebutkan bahwa perairan Teluk Jakarta telah terakumulasi oleh logam berat yang dapat menyebabkan degradasi suatu organisme laut.Konsentrasi logam berat yang tinggi di perairan Teluk Jakarta cukup memberikan dampak negatif pada kehidupan organisme yang ada (Sachoemar dan Wahjono, 2007; Suseno, 2007; Arifin dan Fadhlina, 2009). Berdasarkan hasil penelitian Mustarudin (2013), ikan dari hasil tangkapan nelayan terdapat kandungan kadar Mercury $(\mathrm{Hg})$ dan Timbal $(\mathrm{Pb})$ telah melebihi baku mutu. Konsentrasi logam Timbal $(\mathrm{Pb})$, Kadmium $(\mathrm{Cd})$, Tembaga $(\mathrm{Cu})$ dan Seng (Zn) telah terakumulasi pada kerang hijau (Perna viridis) yang terdapat pada perairan Teluk Jakarta (Arifin dan Fadhlina, 2009).

Menurut Wicaksono et al. (2013) kadar logam berat yang melebihi ambang batas dapat membahayakan kehidupan organisme karang. Panuntun et al. (2012) jenis karang Acropora aspera dapat mengakumulasi logam berat $\mathrm{Pb}$ (timbal) dengan konsentrasi $0,010 \mathrm{mg} / \mathrm{l}$. Sedimentasi yang di hasilkan oleh sungai-sungai yang mengalir ke perairan Teluk Jakarta memberikan efek terhadapkehidupan organisme karang. Menurut Weber et al. (2012), akumulasi sedimen pada suatu perairan dapat menyebabkan terjadinya kerusakan organisme karang. LIPI (2010) menyimpulkan tingkat kekeruhan yang disebabkan oleh sungai-sungai yang bermuara pada Teluk Jakarta berpotensi memberikan dampak pada kondisi terumbu karang.Persen tutupan karang yang buruk sangat tergantung dengan kondisi perairan sekitar dan faktor-faktor lain. Karang dengan tutupan yang rendah dapat diindikasikan terjadinya kerusakan, baik yang disebabkan oleh kondisi perairan yang buruk atau disebabkan terjangkit penyakit.
Penyakit karang didefinisikan sebagai kondisi yang tidak normal. Kondisi yang tidak normal tersebut disebabkan oleh faktor ekternal yang dapat menyebabkan kerusakan karang baik karena pemutihan (Tissier, 1996; Obura, 2009) dan penyakit karang (Richmond, 1993). beberapa faktor lain yang dapat meningkatkan stres hingga menyebabkan kematian antara lain : peningkatan dan penurunan suhu (Kushmaro et al, 1998; Baird dan Marshall, 2007; Yee et al., 2011), peningkatan radiasi matahari yang tinggi (Tissier dan Brown, 1996; Yee et al., 2011), sedimentasi yang tinggi (Weber et la, 2012), predator yang terdapat di perairan tersebut (Rotjan dan Lewis, 2008) dan tekanan antropogenik.

Subhan et al. (2011) menyebutkan sebesar $18.46 \%$ pemutihan karang terjadi pada Genus Fungidae yang terdapat pada pulau Pramuka Kepulauan Seribu. Yusran dan Estradivari (2009) melaporkan terdapat jenis penyakit karang White Syndrome dan pemutihan karang di Kepulauan Seribu bagian utara. Johal et al. (2012) kelimpahan penyakit Black Band Disease (BBD) terjadi di Pulau Pramuka bagian utara $(0.15 \mathrm{kol} / \mathrm{m})$, Pulau Pari bagian timur $(0.092 \mathrm{kol} / \mathrm{m})$, Pulau Penjaliran $(0.092 \mathrm{kol} / \mathrm{m})$, dan Pulau Tikus $(0.085 \mathrm{kol} / \mathrm{m})$. Subhanet al. (2011) menyebutkan terdapat 5 genus (marga) karang dari Famili Fungiidae (Sandalolitha, Ctenactis, Fungia, Herpolitha, Heliofungia) yang terserang oleh penyakit Yellow Band Disease (YBD), Sedimentasi, dan Bleaching (putih). Penelitian penyakit karang yang dilakukan oleh Yusran dan Estradivari, 2009; Subhan et al, 2011; Johan et al, 2012, Johan et al, 2015 dilakukan pada lokasi pulau-pulau kecil bagian utara Kepulauan Seribu sedangkan pada pulau-pulau kecil di bagaian selatanKepulauan Seribu belum ada penelitian yang melaporkan kondisi kesehatan karang pada pulau-pulau kecil yang berhadapan langsung dengan Teluk Jakarta. Kondisi perairan Teluk Jakarta dengan tingkat pencemaran yang tinggi dan rencana pembangunan Giant Sea Wall (GSW) sebagai dasar dilakukannya penelitian ini. Dari uraian 
tersebut diatas, maka penelitian ini bertujuan 1). Mengetahui kondisi terumbu karang di pulaupulau kecil Teluk Jakarta, 2). Mengetahui sebaran penyakit karang di pulau-pulau kecil Teluk Jakarta. 3). Menganalisis hubungan kelimpahan penyakit karang, prevalensi penyakit karang terhadap kondisi karang hidup pada pulau-pulau tersebut.

\section{BAHAN DAN METODE}

\section{Lokasi Penelitian}

Pengambilan data dilakukan di Pulau Bokor, Pulau Lancang Kecil, Pulau Kongsi, Pulau Burung dan Pulau Pari, penelitian ini dilakukan pada bulan April 2014.

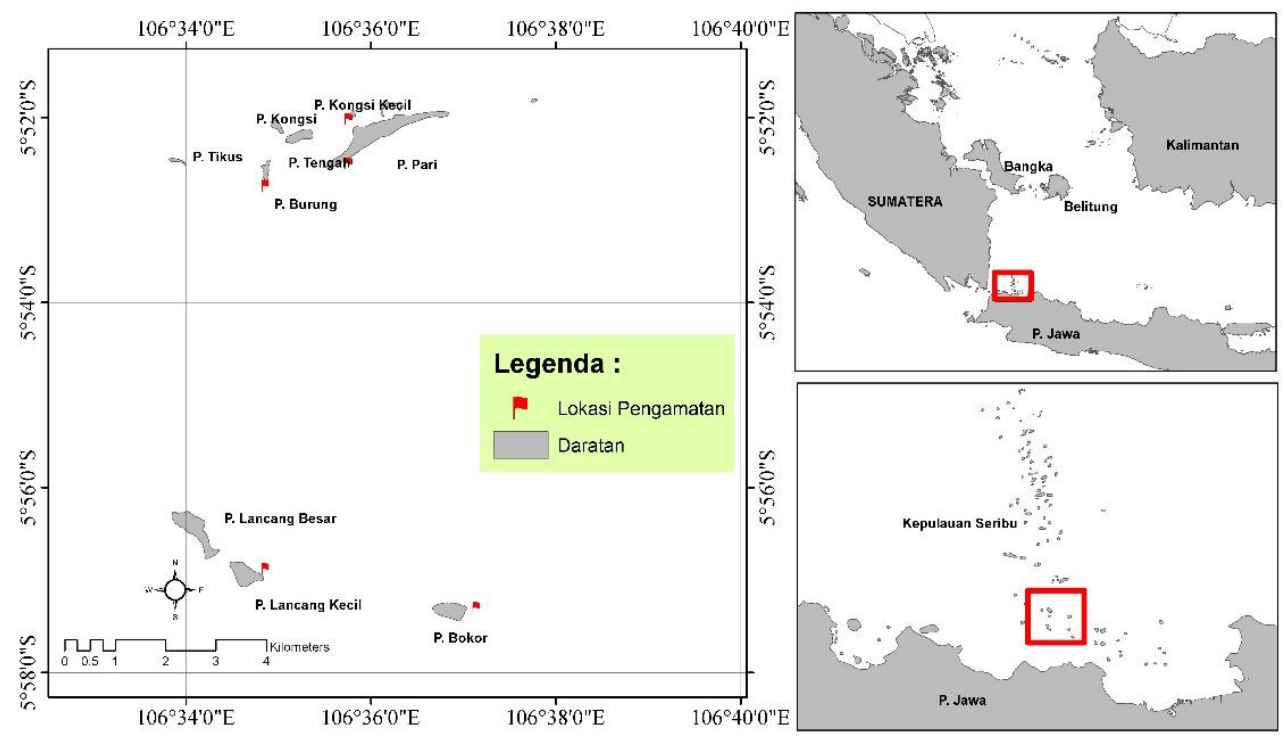

Gambar 1. Peta lokasi peneltian

\section{Kondisi Terumbu Karang dan Penyakit Karang}

Data kondisi terumbu karang diambil dengan metode transek garis (Line Intercept Transect) pada kedalaman 3 (English et al. 1994).Panjang transek yang digunakan yaitu 50 meter.Data karang dicatat meliputi bentuk pertumbuhan karang hidup (life form) dalam bentuk presentase kriteria standar yang mengacu pada Gomenz dan Yap (1988).

Data sebaran penyakit karang diambil menggunakan metode transek sabuk (Belt Transect) pada kedalaman 3 meter. Panjang transek 50 meter dan lebar 1 meter kanan 1 meter kiri. Data penyakit karang diambil dan di identifikasi sesuai buku panduan penyakit karang menurut (Beedenet al., 2008; Raymundo et al., 2008). Identifikasi karang sampai dengan level genus berdasarkan buku panduan Veron (2000) Volume 1,2 dan 3 dengan acauan kunci identifikasi Coral Finder 2.0 Indo Pacific (Kelley, 2009).

\section{Analisis data}

Untuk mengetahui kondisi terumbu karang pada lokasi pengamatan dilakukan perhitungan persen tutupan karang hidup (Tabel 1). Persamaan yang digunakan dalam menghitungbentuk pertumbuhan karang(Lifeform) menggunakan perhitungan menurut Englishet.al (1994) yaitu :

$$
L i=\frac{n i}{L} x 100 \%
$$

\section{Keterangan:}

$\mathrm{Li} \quad=$ persentase penutupan biota karang ke-i

ni = panjang total kelompok biota karang kei

$\mathrm{L} \quad=$ panjang total transek 
Tabel 1. Kriteria penentuan kondisi terumbu karang berdasarkan persen tutupan karang hidup

\begin{tabular}{cc}
\hline Kategori & Persen tutupan karang hidup (\%) \\
\hline Buruk & $0-19,9$ \\
Sedang & $20-49,9$ \\
Baik & $50-74,9$ \\
Sangat baik & $75-100$ \\
\hline
\end{tabular}

Sumber: Gomes dan Yap (1988)

\section{Sebaran penyakit karang}

Untuk mengetahui prevalensi karang dilakukan perhitungan dengan membandingkan Jumlah koloni karang yang terserang suatu jenis penyakit dibagi dengan jumlah total koloni yang terserang penyakit di kali $100 \%$ dengan rumus menurut Muller dan Van Woesik (2011) sebagai berikut:

$$
P=\frac{P i}{P o} x 100 \%
$$

\section{Keterangan:}

$\mathrm{P} \quad=$ Persentase Prevelensi

$\mathrm{Pi} \quad=$ Jumlah Koloni karang yang terserang penyakit ke-i

Po $\quad=$ Total koloni yang terserang penyakit

Persentase karang hidup pada lokasi pengamatan termasuk dalam kategori buruk hingga sedang (Tabel 1). persentase tutupan karang hidup pada Pulau Bokor $(0,65 \%)$, Pulau Lancang Kecil (5,05\%), Pulau kongsi (17,88\%), Pulau Burung $(25,08 \%)$ dan Pulau Pari $(41,27 \%)$ Gambar 2. Persentase tutupan karang pada pulau Bokor, Pulau Lancang Kecil dan Pulau Kongsi dalam kategori buruk. Kondisi persentase karang yang terdapat pada Pulau
Perhitungan kelimpahan penyakit karang menggunakanrumus kelimpahan menurut Odum (1993) sebagai berikut :

$$
X i=\frac{x i}{n}
$$

\section{Keterangan:}

$\mathrm{Xi}=$ Kelimpahan penyakit karang ke $-\mathrm{i}$

$\mathrm{xi}=$ Jumlah Individu yang terserang penyakit

$\mathrm{n}=$ Luas Area pengamatan

untuk mengetahui Hubungan persen tutupan, kelimpahan penyakit dan prevalensi penyakit, dianalisis dengan metode regresi linier.

\section{HASIL DAN PEMBAHASAN}

\section{Kondisi Terumbu Karang}

Bokor dan Pulau Lancang Kecil sangat dipengaruhi oleh kondisi perairan sekitarnya. Tingkat kekeruhan yang terjadi disebabkan oleh asupan aliran sungai dari Teluk Jakarta menyebabkan kondisi terumbu karang di pulau tersebut semakin buruk. LIPI (2010) menyimpulkan tingkat kekeruhan yang disebabkan oleh sungai-sungai yang bermuara pada Teluk Jakarta berpotensi memberikan dampak pada kondisi terumbu karang 


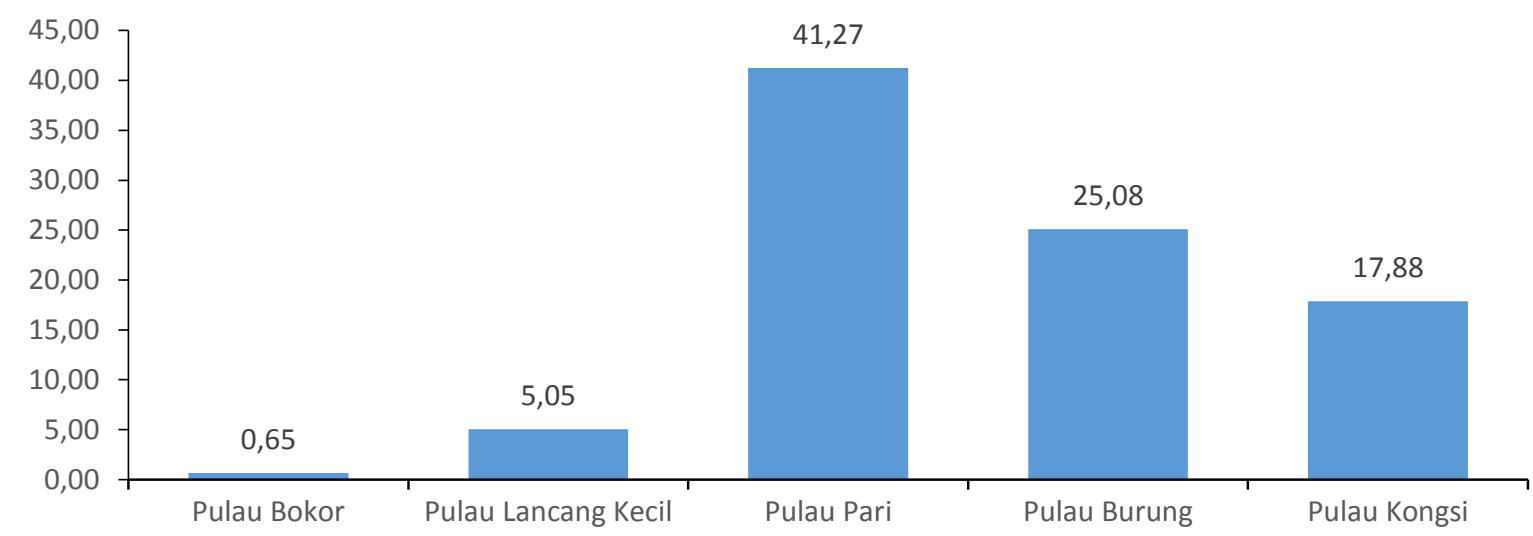

Gambar 2.Grafik persentase tutupan karang hidup pada pulau-pulau kecil Teluk Jakarta.

Aliran sungai-sungai tersebut membawa sedimentasi dari daratan yang sehingga sangat berpengaruh pada kesehatan karang. Hal ini terlihat dari beberapa penelitian sebelumnya yang menyebutkan semakin tinggi tingkat sedimentasi maka semakin rendah karang hidup yang di temukan. Seperti halnya pada Pulau Bokor dan Pulau Lancang Kecil dengan persen tutupan karang hidup yang ditemukan dalam kategori buruk (rusak) menunjukkan bahwa pengaruh sedimentasi dari aktivitas daratan Teluk Jakarta memberikan efek yang buruk untuk kelestarian terumbu karang yang terdapat pada pulau-pulau kecil yang berhadapan langsung dengan Teluk Jakarta. Persentase tutupan karang hidup pada pulau Pari dan Pulau Burung masih dalam kategori sedang. Nilai persentase tutupan karang hidup mencapai 25,08\% (Pulau Burung) dan 41,27\% (Pulau Pari) kondisi tersebut dikarenakan tingkat kekeruhan di pulau Pari dan Pulau Burung rendah. Asupan sedimentasi dari aliran sungai teluk Jakarta belum mencapai palu-pulau tersebut.

\section{Sebaran dan Kelimpahan Penyakit Karang}

Tingkat Kemunculan penyakit karang yang di sebabkan oleh warna seperti Black Band Disease, Yellow Band Disease dan yang lain sangat sedikit ditemukan pada lokasi pengamatan. Sedangkan kelompok compromised Health (pengganggu karang) banyak ditemukan pada lokasi pengamatan (Tabel 2). Kelompok pengganggu yang banyak ditemukan pada setiap lokasi yaitu
Pigmentation Respon, Spon Over, Sedimentation Damage, Fish Bites, Crown-OfThorns Starfish (COTS), Drupelladan Invertabrate Galls. Kelompok pengganggu yang tinggi ditemukan yaitu Sedimentation Damege, hal ini dikarenakan pada perairan gugusan pulau kecil Teluk Jakarta terkontaminasi oleh aliran sedimentasi dari daratan Jakarta. Tingkat sedimen tersebut menyebabkan banyaknya ditemukan karang-karang yang tertutup sedimen hingga mengalami kematian.Bartley et. al. (2014) menyebutkan peningkatan sedimen dan kekeruhan dapat menyebabkan kerusakan pada ekosistem terumbu karang, penambahan dan peningkatan sedimentasi bisa terjadi akibat peningkatan aktivitas antropogenik dari daratan. Weber et al (2012) menjelaskan efek sedimentasi sangat berdampak pada kerusakan jaringan karang. Laju sedimentasi sangat berpengaruh pada pertumbuhan karang (Adriman et. al. 2013). Erftemeijer et. al. (2012) sebagian besar jenis karang sangat sensitif terhadap peningkatan sedimentasi tinggi menyebabkan penurunan intensitas cahaya matahari dan berdampak pada meningkatnya stres pada polip hingga menyebabkan kematian karang. Pemutihan karang juga ditemukan pada beberapa lokasi pengamatan. Pemutihan karang yang terjadi dalam bentuk Strip, Pacth,Spothingga putih seluruhnya. Pemutihan karang merupakan respons karang terhadap perubahan lingkungan khususnya pada perubahan suhu permukaan air laut yang memberikan dampak stres pada karang (Baird, 2002). Radiasi matahari menyebabkan menurunkan kepadatan zooxanthella yang merupakan alga pewarna pada karang sehingga 
menyebabkan pemutihan karang yang signifikan (Tissier dan Brown, 1996).

Pigmentaion respons juga merupakan pengganggu kesehatan yang ditemukan pada setiap lokasi pengamatan. Pigmentation respons banyak ditemukan pada karang-karang massive dari genus Porites. pemudaran warna (tissue discoloration) dengan munculnya warna merah mudah atau ungu pada permukaan karang tersebut menandakan kesehatan karang tersebut terganggu. Benzoni (2009) menjelaskan bahwa respons dari munculnya bintik-bintik warna merah mudah atau ungu merupakan pengaruh dari mekanisme stres karang yang disebabkan oleh larva Cirripedia yang menempel pada permukaan karang hidup pada genus Porites.

Sedimentation demage juga merupakan gangguan kesehatan karang yang dijumpai pada setiap lokasi pengamatan, kondisi ini disebabkan tingginya aktivitas pada daratan Jakarta yang membawa sedimentasi hingga ke perairan pulau kecil di sekitar Teluk Jakarta. Sedimentasi merupakan faktor penting dalam tingkat stres yang terjadi pada karang. Beberapa spesies karang mengalami degradasi oleh tingginya tingkat sedimentasi di satu perairan. Gleason (1998) karang jenis P.Astreoides mampu mentoleransi tingkat sedimen yang tinggi. Rogers (1990) peningkatan sedimentasi menyebabkan degradasi terumbu karang pada satu wilayah, partikel sedimen yang menutupi organisme karang dan mengurangi cahaya yang dibutuhkan untuk proses fotosintesis. Sedimentasi yang berlebihan dapat mengubah struktur komunitas karang baik secara fisik maupun secara biologis. Penyakit White syndrome ditemukan pada 3 lokasi pengamatan. White syndrom merupakan penyakit karang yang terjadi akibat kehilangan jaringan pewarna karang. Kehilangan jaringan pada karang tersebut disebabkan beberapa faktor seperti predator dan persaingan antara organisme karang dan jamur,ganggang ataupun spons. Menurut Work dan Aeby (2011) penyakit White syndrome terjadi karena adanya mikroorganisme yang menyebarkan penyakit ketika terjadinya luka pada karang jenis Acropora. Rotjan dan Lewis (2008) menjelaskan bahwa predator seperti Acanthaster panci dapat merusak jaringan karang hingga menjadi putih. Aebyet al.(2010) kualitas perairan dapat mempengaruhi penyebaran penyakit karang White syndrome pada karang jenis Montipora, hal ini dikarenakan beberapa jenis penyakit karang sangat berpengaruh oleh tekanan lingkungan di suatu perairan yang dapat menyebabkan terjadinya beberapa penyakit karang.

Tabel 2. Sebaran Penyakit Karang

\begin{tabular}{clccccc}
\hline Kategori & Jenis & P. Bokor & P. L. Kecil & P. Pari & P. Burung & P. Kongsi \\
\hline \multirow{3}{*}{ Penyakit } & SEB & & & $*$ & $*$ & \\
& BrB & & & $*$ & $*$ & \\
& WS & & & $*$ & $*$ & $*$ \\
\hline \multirow{5}{*}{ Pemutihan } & Full & & & $*$ & $*$ & $*$ \\
& Spots & & $*$ & $*$ & $*$ & $*$ \\
& Patches & & $*$ & & & \\
& Stripes & & $*$ & $*$ & & \\
Gangguan & Fish & $*$ & & $*$ & & \\
Kesehatan & Dru & $*$ & & $*$ & $*$ & \\
& PR & $*$ & $*$ & $*$ & $*$ & \\
& IG & & & $*$ & $*$ & \\
& SP & $*$ & $*$ & $*$ & $*$ & \\
& SD & $*$ & $*$ & $*$ & $*$ & \\
\hline
\end{tabular}

Keterangan: * = ditemukan, SEB = Skeletal Eroding Band, $\mathrm{BrB}=$ Brown Band Disease, WS =White Syndrom, Full $=$ Putih seluruhnya, Spots $=$ Bintik Puith, Patches $=$ Tambalan putih, Stripe $=$ Garis putih, Fish $=$ Fish bite, Dru $=$ Drupellla, COTS $=$ Crown-of-Thorns Starfish, PR $=$ Pigmentation Respon, $\mathrm{IG}=$ Invertebrate Galls, $\mathrm{SP}=$ Spons Over, $\mathrm{SD}=$ Sedimentation Damage. 
Pemutihan karang yang ditemukan pada lokasi penganan dikategorikan menjadi 4 yaitu Pacth, putih keseluruhan, strip, dan spot (bintik-bintik). Pemutihan karang terjadi akibat hilangnya organisme karang (zooxanthella) yang keluar dari polip karang (Douglas, 2003). Pemutihan karang pada daerah Kepulauan Seribu dilaporkan oleh beberapa peneliti sebelumnya. Subhanet. al. (2011) sebesar $18.46 \%$ pemutihan karang terjadi pada Genus Fungidae yang terdapat pada pulau Pramuka Kepulauan Seribu. Pemutihan karang umumnya dikategorikan dalam jenis penyakit karang yang disebabkan oleh tekanan lingkungan seperti naiknya suhu permukaan laut (Yee et. al. 2008; Glynn,1993; Cervino et al, 2004; McClanahan, 2004), penuruan suhu laut (Coles dan Fadlallah,1991) dan peningkatan radiasi matahari (Tissier dan Bronw, 1996). Pemutihan karang merupakan tanggapan terhadap perubahan lingkungan yang menyebabkan keluarnya polip karang ketika terjadinya stres pada karang (Hayes dan Goreau, 1992). Selain suhu yang dapat menyebabkan terjadinya pemutihan karang, salinitas merupakan salah satu faktor yang berdampak pada terjadinya pemutihan karang, perubahan salinitas yang drastis akan menyebabkan suplai nutrien pada zooxanthellae berkurang dan hal ini dapat menghambat pertumbuhan karang dan keseimbanganzooxanthellae terganggu (Stimson dan Kinzie, 1991). Kelimpahan penyakit karang pada lokasi pengamatan di sajikan pada Gambar 3.

Kelimpahan penyakit karang yang ditemukan pada lokasi penelitian seperti WhiteSyndrom (WS), Bleaching, Bronw Band Disease (BrB), Skeletal Eroding Band (SEB) dan kelompok compromised Health (pengganggu karang). Beberapa peneliti telah melaporkan keberadaan penyakit karang yang terdapat di Kepulauan Seribu. Penyakit White Syndrome banyak ditemukan pada setiap ditemukan di lokasi pengamatan. Yusran dan Estradivari (2009) melaporkan bahwa terdapat jenis penyakit karang White Syndrome dan pemutihan karang di Kepulauan Seribu. Subhanet al. (2011) menyebutkan terdapat 5 genus (marga) karang dari Famili Fungiidae (Sandalolitha, Ctenactis, Fungia, Herpolitha, Heliofungia) yang terserang oleh penyakit Yellow BandDisease (YBD), Sedimentasi, dan Bleaching (putih). Johan et al. (2014) tinggal prevalensi penyakit sabuk hitam (Black Band Disease) yang di Kepulauan Seribu mencapai $12,53 \%$, puncak terjadinya penyakit karang jenis ini pada musim peralihan antara musim kemarau dan musim penghujan. Pada pengamatan yang dilakukan kelimpahan penyakit karang yang ditemukan pada seluruh lokasi pengamatan sangat sedikit. Penyakit yang ditemukan antara lain: 17 koloni yang terserang WhiteSyndrom (WS), 65 koloni (putih) Bleaching, 2 koloni yang terserang Brown Band Disease (BrB), 1 koloni yang terserang Skeletal Eroding Band (ESB). Sedangkan kategori gangguan kesehatan karang seperti Fish bite (4 koloni), Drupellla (2 koloni), Crown-Of-Thorns Starfish (COTS) (1 koloni), Pigmentation Respon (31 koloni), Invertebrate Galls (13 koloni), Spons Over (30 koloni), dan SedimentationDemage (64 koloni). 


\section{Pulau Pari}

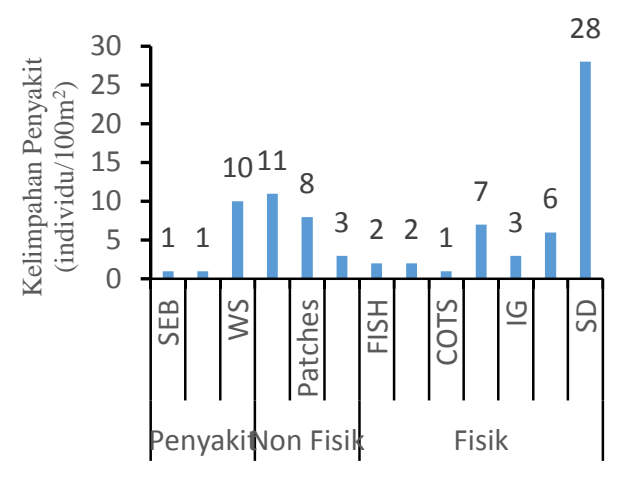

\section{Pulau Kongsi}

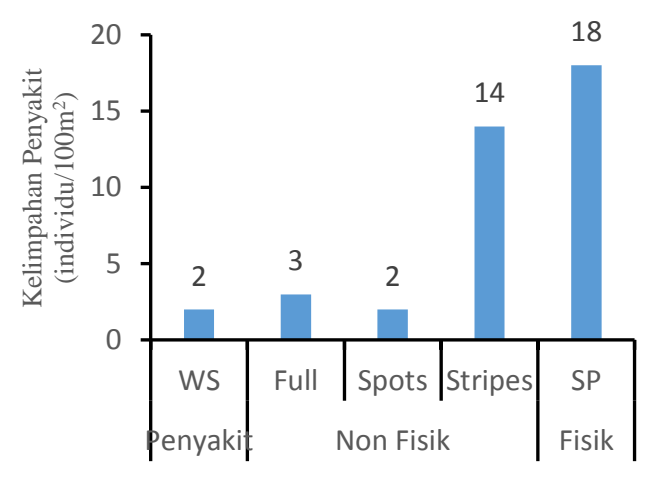

Pulau Burung

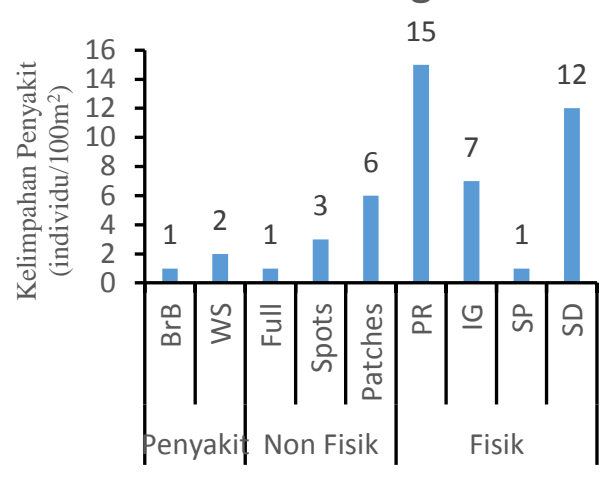

Pulau Bokor

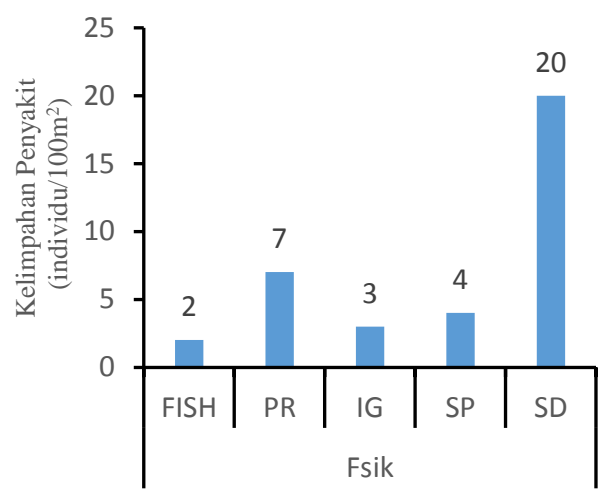

\section{Pulau Lancang Kecil}

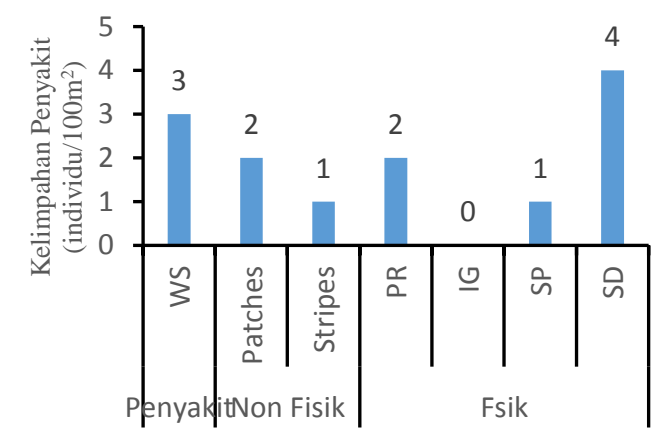

Gambar 3.Grafik kelimpahan penyakit karang pada pulau-pulau kecil Teluk Jakarta

Prevalensi penyakit karang (Gambar 4) yang terdapat pada lokasi pengamatan sangat kecil. Prevalensi penyakit yang ditemukan seperti SEB $(0,46 \%)$, BrB (0,93\%), WS (6,48\%). Sedangkan prevalensi gangguan kesehatan karang seperti sedimentation demage $(37,96 \%)$ dan Pigmentation Respon(20,83\%). Prevalensi sedimentation semage yang tinggi disebabkan oleh aliran sedimen yang berasal dari daratan Teluk Jakarta yang terbawa kelaut, yang berakibat pada beberapa koloni karang tertutup sedimen. Hosono et. al. (2011) menjelaskan bahwa akumulasi logam antropogenik dalam sedimen teluk Jakarta telah terjadi pada tahun 1920 hingga 1970 dan berakhir pada tahun 1990. Sejak tahun 1990 hingga 2006 tingkat akumulasi konstan pada daerah industri yang dekat dengan pesisir. Menurut Weber (2012) limpasan sedimen yang menumpuk pada karang akan menjadi kunci kematian karang hal tersebu dikarenakan sedimen yang kaya akan bahan organ menyebabkan peningkatan konstatasi

JURNAL KELAUTAN NASIONAL, Vol. 11, No. 3, Desember 2016, Hal. 175-187 
hidrogen sulfida yang dapat meningkatkan degradasi lendir karang dan menyebabkan kematian jaringan karang. Prevalensi Pigmentation Respon juga merupakan tingkat gangguan kesehatan karang yang tinggi. Pigmentation respons terjadi akibat oleh larva Cirriped yang menempel pada permukaan karang hidup pada genus Porites.Pigmentation Respon (pink blue) terjadi dikarenakan tekanan antropogenik yang menyebabkan systemmetabolisme pada karang terganggu sehingga menyebabkan munculnya warna pink blue pada beberapa karang Porites. Menurut Soenardjo (2013) penyakit sindrome pinkblotchdapat disebabkan oleh agen tunggal penyakit yang disebabkan oleh bakteri Erythrobacter sp.

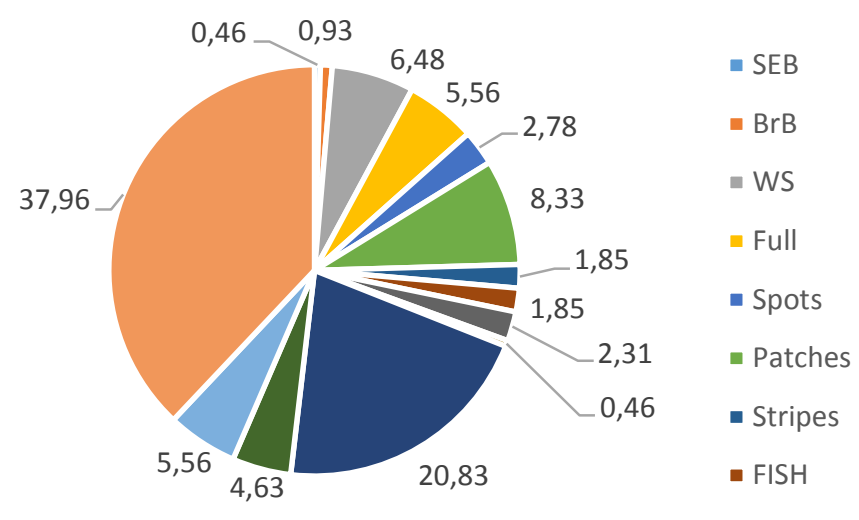

Gambar 4. Grafik prevalensi penyakit karang pada pulau-pulau kecil Teluk Jakarta

Hubungan persentase tutupan karang hidup, kelimpahan penyakit dan prevalensi penyakit karang menunjukan hubungan yang erat dimana nilai korelasi mendekati 1 dengan nilai korelasi masing-masing $0,8658, \quad 0,9139$ dan 0,7794 (Gambar 6) nilai tersebut menunjukkan bahwa persen tutupan karang hidup memiliki keterkaitan (hubungan)yang erat terhadap kelimpahan penyakit karang. Hal ini disebabkan tingkat kelimpahan penyakit karang dipengaruhi oleh faktor lingkungan yang menyebabkan terjadinya degradasi pada ekosistem terumbu karang. Hubungan antara tutupan karang hidup dan prevalensi penyakit karang juga memiliki nilai yang sangat erat $(0,7794)$ dan hubungan prevalensi dengan kelimpahan penyakit karang juga memiliki hubungan yang erat $(0,8658)$. Hubungan antara ketiga parameter tersebut menunjukkan keterkaitan antara satu dengan yang lain. Dimana semakin tinggi nilai tutupan karang hidup pada lokasi pengamatan, maka semakin tinggi pula nilai prevalensi dan kelimpahan penyakit karang yang terdapat pada lokasi pengamatan. 

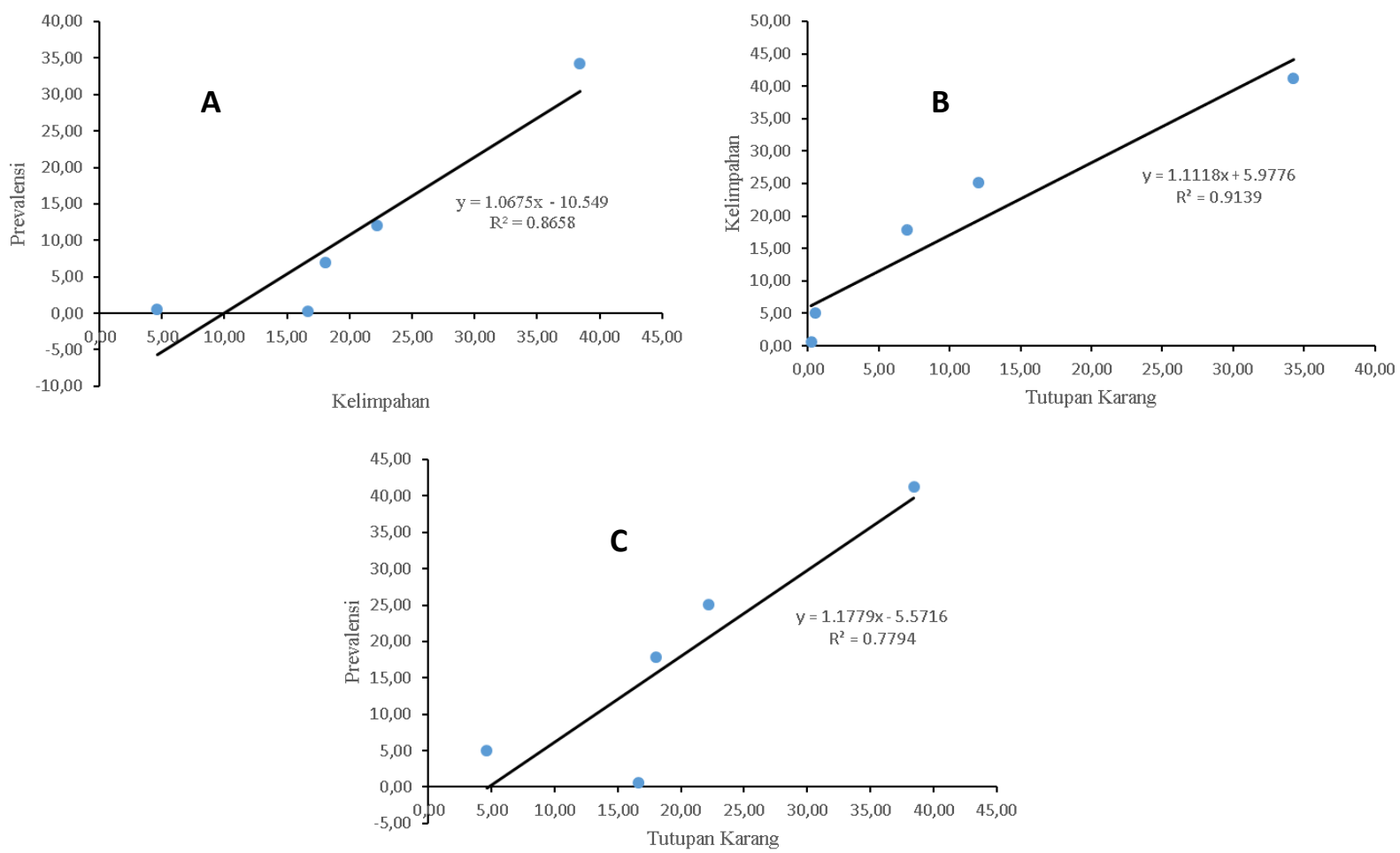

Gambar 6.Grafik hubungan persen tutupan karang hidup,kelimpahan penyakit, dan prevalensi penyakit pada lokasi pengamatan.A). Hubungan prevalensi dan kelimpahan penyakit B) Hubungan kelimpahan penyakit dan tutupan karang hidup C) hubungan prevalensi dan tutupan karang hidup.

\section{KESIMPULAN DAN SARAN}

Tekanan antropogenik yang terjadi pada perairan teluk Jakarta menyebabkan sistem metabolisme karang diperairan pulau-pulau kecil Teluk Jakarta terganggu. Pulau Bokor dan Pulau Lancang kecil merupakan pulau yang dekat dengan Teluk Jakarta dan mendapatkan tekanan yang tinggi, dimana persen tutupan karang hidup pada pulau Bokor 0,65 \% dan pulau Lancang Kecil 5,05\%. Kondisi ini memperlihatkan bahwa tekanan lingkungan memberikan dampak yang cukup besar terhadap kesehatan karang di lokasi pengamatan. Pulau

Pari dan pulau Burung masih dalam kategori sedang dengan nilai persen tutupan karang pada pulau pari $41,27 \%$ dan pulau burung $25,08 \%$.

Kelimpahan penyakit yang ditemukan antara lain: 17 koloni yang terserang WhiteSyndrom (WS), 65 koloni (putih) Bleaching, 2 koloni yang terserang Brown Band Disease (BrB), 1 koloni yang terserang Skeletal Eroding Band (ESB). Kategori gangguan kesehatan karang seperti Fish bite (4 koloni), Drupellla (2 koloni), Crown-Of-Thorns Starfish (COTS) (1 koloni), Pigmentation Respon (31 koloni), Invertebrate Galls (13 koloni), Spons Over (30 koloni), dan Sedimentation Demage (64 koloni).

Prevalensi penyakit yang ditemukan seperti Skeletal Eroding Band (SEB) 0,46\%, Brown Band Disease (BrB) 0,93\%, White Syndrom (WS) 6,48\%. Prevalensi gangguan kesehatan karang seperti sedimentation demage (SD) 37,96\% dan Pigmentation Respon (PR) 20,83\%. Kontribusi dari persen tutupan karang dapat meningkatkan prevalensi dan kelimpahan penyakit pada lokasi pengamatan. Hal ini terlihat semakin tinggi tutupan karang hidup maka semakin tinggi (banyak) penyakit dan gangguan kesehatan karang yang ditemukan pada lokasi pengamatan.

\section{DAFTAR PUSTAKA}

Adriman, P., S. Budiharso, dan A. Damar. 2014. Pengaruh sedimentasi terhadap terumbu karang di kawasan konservasi laut daerah bintan timur kepulauan riau. 
J.Berkala perikanan Terubuk, 41(1), 90-101.

Aeby, G. S., M. Ross, G. J.Williams,T. D.Lewis, andT. M. Work. 2010. Disease dynamics of Montipora white syndrome within Kaneohe Bay, Oahu, Hawaii: distribution, seasonality, virulence, and transmissibility. Diseases of aquatic organisms, 91(1), $1-8$.

Arifin, Z. A., dan D.Fadhlina, 2010. Fraksinasi Logam Berat $\mathrm{Pb}, \mathrm{Cd}, \mathrm{Cu}$ dan $\mathrm{Zn}$ dalam Sedimen dan Bioavailabilitasnya bagi Biota di Perairan Teluk Jakarta.J. Ilmu Kelautan,14(1): 27-32.

Baird, A. H., and P. A.Marshall. 2002. Mortality, growth and reproduction in scleractinian corals following bleaching on the Great Barrier Reef. $J$. Marine Ecology Progress Series, 237: 133-141.

Barnard, N., and C. Scheske. 2010. Disease in Tropical Coral Reef Ecosystems: ICRI Key Messages on Coral Disease. 11.

Bartley, R., Z. T. Bainbridge, S. E Lewis, F. J.Kroon,S. N. Wilkinson, J. E Brodie, and D. M. Silburn. 2014. Relating sediment impacts on coral reefs to watershed sources, processes and management: A review. J. Science of the Total Environment, 468-469:11381153.

Beeden, R., B.L. Willis, L. Raymundo, C. A. Page, and E. Weil. 2008. Underwater cards for assessing coral health on Indo-Pacific reefs. Coral Reef Targeted Research and Capacity Building for Management Program. Currie Communications, Melbourne, 22p.

Benzoni, F., P. Galli, and M. Pichon. 2010. Pink spots on Porites: not always a coral disease. J.Coral reefs, 29(1):153-153.

Cervino, J. M.,R. Hayes, T.J. Goreau, and G.W.Smith. 2004. Zooxanthellae regulation in yellow blotch/band and other coral diseases contrasted with temperature related bleaching: In situ destruction vs expulsion. J. Symbiosis, 37(1/3), 63-86.

Coles, S. L., andY. H. Fadlallah. 1991. Reef coral survival and mortality at low temperatures in the Arabian Gulf: new species-specific lower temperature limits. J. Coral Reefs, 9(4):231-237.

Douglas, A. E. 2003. Coral bleaching -how and why?.J.Marine pollution bulletin, 46(4):385-392.

English, C. Wilinson, and V .Baker.1994.Survey Manual for Tropical Marine Resources. ASEANAustralia Marine Science Project: Living Coastal Resources. Australian Institute of Marine Science. Townsville.

Erftemeijer, P. L., B. Riegl, B.W.Hoeksema, and P.A.Todd. 2012. Environmental impacts of dredging and other sediment disturbances on corals: a review. J. Marine Pollution Bulletin, 64(9):1737-1765.

Estradivari, E. Setyawan, dan S. Yusri. (Eds). 2009. Terumbu Karang Jakarta: Pengamatan Jangka Panjang Terumbu Karang Kepulauan Seribu (2003-2007). Yayasan Terangi, Jakarta. 102hlm.

Gleason, D. F. 1998. Sedimentation and distributions of green and brown morphs of the Caribbean coral Porites astreoides Lamarck.J.of experimental marine biology and ecology, 230(1):73-89.

Glynn, P. W. 1993. Coral reef bleaching: ecological perspectives. J. Coral reefs, 12(1):1-17.

Gomez, E.D. and Yap, H.T. 1988. Monitoring Reef Condition. In Kenchington R A and Hudson B E T (ed). Coral Reef Management Hand Book.UNESCO.Regional Office for Science and Technology for South East Asia Jakarta.

Hawker, D.W., and D.W.Connell. 1992. Pollution in Tropical Aquatic Systems. CRC Press, Inc. London.

Hayes, R.I., and T.J. Goreau. 1992. Histology of Caribbean and south Pacific bleached corals. Proc. 7th Int. Coral Reef Symp, 1: 71pp.

Hosono, T., C.C. Su, R. Delinom, Y. Umezawa, T. Toyota,S. Kaneko, and M. Taniguchi. 2011. Decline in heavy metal contamination in marine sediments in Jakarta Bay, Indonesia due to increasing environmental 
regulations. J. Estuarine, Coastal and Shelf Science, 92(2):297-306.

Johan, O., A.H. Kristanto, J. Haryadi, dan I.N. Radiarta. (2014). Puncak Prevalense Penyakit Karang Sabung Hitam (Black Band Disease) di Kepulauan Seribu, Jakarta.J. Riset Akuakultur, 9(2): 295305.

Johan, O., D. G.Bengen, dan N. P. Zamani. 2012. Distribution and Abundance of Black Band Disease on Corals Montipora sp in Seribu Islands, Jakarta. $J$. of Indonesian Coral Reefs, 1(3): $160-170$.

Kelley, R. 2009. Coral Finder 2.0 Indo Pacific.The Australia Coral Reef Society. Australia. 34p.

Kushmaro, A., E. Rosenberg, M. Fine, Y. Ben Haim, and Y. Loya. 1998. Effect of temperature on bleaching of the coral Oculina patagonica by Vibrio AK-1. J.Marine Ecology Progress Series, 171:131-137.

Le Tissier, M. D. A. A., and B. E. Brown. 1996. Dynamics of solar bleaching in the intertidal reef coral Goniastrea aspera at Ko Phuket, Thailand. J.Marine Ecology Progress Series, 136:235-244.

Lembaga Ilmu Penelitian Indonesia (LIPI).2010. Laporan Akhir Program Insentif Peneliti dan Perekayasa: Pengaruh Kekeruhan Terhadap Ekosistem Terumbu Karang di Kepulauan Seribu. Jakarta.52hlm.

McClanahan, T. R. 2004. The relationship between bleaching and mortality of common corals.J.Marine Biology, 144(6):1239-1245.

Muller, E. M., and R.V. Woesik. 2011. Blackband disease dynamics: Prevalence, incidence, and acclimatization to light. $J$. of experimental marine biology and ecology, 397(1), 52-57.

Mustaruddin. 2013. Pola Pencemaran $\mathrm{Hg}$ dan $\mathrm{Pb}$ pada Fishing Ground dan ikan yang tertangkap nelayan: Studi kasus di Telu Jakarta. J. Bumi Lestari,13(2):214-224.

Obura, D. O. 2009. Reef corals bleach to resist stress. J.Marine Pollution Bulletin, 58(2):206-212.

Odum, E.P. 1993. Dasar-dasar ekologi (terjemahan). Gadjah Mada University Press. Yogyakarta. 574hlm.
Panuntun, P, B. Yulianto, dan Ambariyanto. 2012. Akumulasi Logam Berat $\mathrm{Pb}$ pada Karang Acropora aspera: Studi Pendahuluan. J. Of Marine Research, 1(1):153-158.

Raymundo, L. J., C. S. Couch, A. W. Bruckner, C. D. Harvell, T. M. Work, E. Weil, C. M Woodley, E. J. Dahlgren, B. L.Willis, Y. Sato, And G.S. Aeby. 2008. Coral Disease HandBook. Coral Reef Targeted Research and Capacity Building for Management Program, c/- Centre for Marine Studies, Gerhmann Building, The University of Queensland, St Lucia, Qld 4072, Australia, 16p.

Richmond, H.R. 1993. Coral Reefs: Present Problems and Future Concerns Resulting from Anthropogenic Disturbance. J.American Zoologist, 33(6):524-536.

Rochyatun, E., dan A. Rozak. 2007. Pemantauan kadar logam berat dalam sedimen di perairan Teluk Jakarta. $J$. Makara Sains, 11(1):28-36.

Rogers, C. S. 1990. Responses of coral reefs and reef organisms to sedimentation.J.Marine ecology progress series, 62(1):185-202.

Rotjan, R. D., andS. M. Lewis. 2008. Impact of coral predators on tropical reefs. J.Marine Ecology Progress Series, 367:73-91.

Rotjan, R. D., and S. M.Lewis.2008.Impact of coral predators on tropical reefs.J.Marine Ecology Progress Series, 367:73-91.

Santavy, D.L., and E.C. Peters. 1997. Microbial pests: Coral disease research in the western Atlantic. Proc. 8th Int. Coral Reef Symp, 1:607-612pp.

Soenardjo, N. 2013.Karakterisasi Bakteri yang Berasosiasi dengan Penyakit PinkBlotchdi P. Sambangan, Karimunjawa.J.Buletin Oseanografi Marina, 2(1):58-65.

Stimson, J, and R.A. Kinzie. 1991. The temporal pattern and rate of release of zooxanthellae from the reef coral Pocillopora damicornis (Linnaeus) under nitrogen-enrichment and control conditions. J.of Experimental Marrine Biology and Ecology, 153:63-74. 
Subhan, B., F. Rahmawati, D. Arafat, dan N.A. Bayu. 2011. Kondisi kesehatan Karang Fungidae di Perairan Pulau Pramuka, Kepulauan Seribu. J.Teknologi Perikanan dan Kelautan, 2(1):41-50.

Veron, J.E.N. 2000a. Corals of the World Volume 1.Australian Institute of Marine Science.Townsville.Australia, 432p.

Veron, J.E.N. 2000b. Corals of the World Volume 2.Australian Institute of Marine Science.Townsville.Australia, 471p.

Veron, J.E.N. 2000c.Corals of the World Volume 3.Australian Institute of Marine Science.Townsville.Australia, 330p.

Weber, M., D.de Beer, C. Lott, L. Polerecky, K. Kohls, R.M.M Abed, and K.E. Fabricius.2012. Mechanisms of damage to corals exposed to sedimentation. J.PNAS, 109(24):E1558-E1567.

Wicaksono, D.B., B. Yulianto, dan Ambariyanto. 2013. Pengaruh Logam Berat Terhadapa Karang.J. Of Marine Research, 2(1):161-166.
Work, T. M., and G. S. Aeby.2011.Pathology of tissue loss (white syndrome) in Acropora sp. corals from the Central Pacific.J.of invertebrate pathology, 107(2):127-131.

Yee, S.H., D.L Santavy, and M. G. Barron. 2011. Assessing the effects of disease and bleaching on Florida Keys corals by fitting population models to data. J.Ecological Modelling, 222(7):13231332.

Yee, S.H., D.L.Santavy, and M.G. Barron. 2008. Comparing environmental influences on coral bleaching across and within species using clustered binomial regression. J.Ecological Modelling, 218(1):162-174.

Suseno, H. 2007. Bioakumulasi kromium oleh Perna viridis Teluk Jakarta berdasarkan studi menggunakan perunut radioaktif ${ }^{51} \mathrm{Cr}$. Prosiding PPI-PDIPTN 2007. Yogyakarta.

Sachoemar, S.I., dan Wahjono, H.D. 2007. Kondisi pencemaran Lingkungan Perairan di Teluk Jakarta. JAI, 3(1): 114. 
